Янковець О. Концептуальна метафора як один із спосоьів номінації ...

УДК 811.11

DOI https://doi.org/10.24919/2308-4863/34-5-27

Олена ЯНКОВЕЦЬ,

orcid.org/0000-0002-1323-8099

аспірант кафедри германського, загального і порівняльного мовознавства

Чернівецьккого національного університету імені Юрія Федьковича

(Чернівці, Україна) alena_kaflevska@ukr.net

\title{
КОНЦЕПТУАЛЬНА МЕТАФОРА ЯК ОДИН ІЗ СПОСОБІВ НОМІНАЦІЇ У ТЕРМІНОСИСТЕМІ ПРИКОРДОННОЇ СФЕРИ
}

\begin{abstract}
Стаття присвячена аналізу особливостей функиіонування концептуальної метафори у терміносистемі прикордонної сфери. Автор характеризує існуючі концептуальні метафори у термінологічному вокабулярі англійської мови та класифікує їх згідно із способом метафоричного перенесення. Метою статті є окреслити основні особливості концептуальної метафори у фаховій мові, а також класифікувати виявлені термінологічні одиниці залежно від способу взаємодії донорської та реципієнтної зони. У наш час у зв'язку із стрімким розвитком наукової думки та технічного прогресу з'являється потреба номінувати нові поняття у фахових терміносистемах тієї чи іншої галузі. Поруч з ефективними шляхами поповнення спеціалізованих вокабулярів, таких, як неосемантизація, транстермінологізація та запозичення, чільне місце посідає метафоризація - явище, яке полягає у використанні об'єкту одного класу з метою позначення об'єкту іншого класу. Концептуальна метафора є однією з форм концептуалізації, тобто когнітивним процесом, який виражає і формує нові поняття. Одними з периих явище метафоризації у науц̧і розглядали А. Річардсон, М. Блек та М. Редді. Основоположниками теорії концептуальної метафори є Дж. Лакофф та М. Джонсон. На изьому етапі розвитку лінгвістичної думки інтерес учених до функиіонування метафори у різних предметних галузях помітно зростає. У нашій роботі ми розглядаємо вісім термінологічних одиниць прикордонної сфери, які належать до категорії «кониептуальна метафора». Нами використовується класифікація кониептуальних метафор, яка базується на типі метафоричного перенесення. У процесі аналізу нами було виявлено, щуо із даної сукупності сім метафор належать до гештальтного типу (з них чотири базуються на основі схожості за зоровою ознакою "колір», один - на основі схожості за зоровою ознакою «артефакт», один - на основі схожості за зоровою ознакою «натурфакт»), $і$ лише одна ТО $\epsilon$ метафорою, яка базується на структурному виді схожості.
\end{abstract}

Ключові слова: концептуальна метафора, теорія, перенесення, тип, гештальт, схожість.

Olena YANKOVETS, orcid.org/0000-0002-1323-8099 Postgraduate Student at the Department of Germanic, General and Comparative Linguistics Yuriy Fedkovych Chernivtsi National University (Chernivtsi,Ukraine) alena_kaflevska@ukr.net

\section{CONCEPTUAL METAPHOR AS ONE OF THE MEANS OF NOMINATION IN THE BORDER GUARD TERMINOLOGY}

The article is devoted to the analysis of the peculiarities of the functioning of the conceptualmetaphor in the terminological system of the border sphere. The author characterizes the existing conceptual metaphors in the terminological vocabulary of the English language and classifies them according to the method of the metaphorical transfer. The aim of the article is to outline the main features of the conceptual metaphor in the professional language, as well as to classify the identified terminological units of the border-guard sphere depending on the method of interaction between the donor and the recipient area. Nowadays, due to the rapid development of the scientific thought and technological progress, there is a need to nominate the new concepts in the professional terminology of a particular field. In addition to the existing effective ways of enriching the specialized vocabulary, such as neosemanticization, transterminology, and borrowing, metaphorization exists as a means of using an object of one class to denote an object of another class. Conceptual metaphor is one of the forms of conceptualization, i.e. a cognitive process that expresses and forms new concepts. A. Richardson, M. Black and M. Reddy were among the first to consider the phenomenon of metaphorization in science. The founders of the theory of conceptual metaphor are J. Lakoff and M. Johnson. At the present stage of development of the linguistic thought, the interest of scientists in the functioning of metaphor in various subject areas is growing significantly. In our work, we consider eight terminological units of the border-guard sphere, which belong to the category of "conceptual metaphor". We use the classification of conceptual metaphors, which is based on the type of metaphorical transference. In the course of the analysis we found, that set seven metaphors belong to the gestalt type (four of them are based on the similarity of the visual sign "color", one - on the basis of similarity on the visual sign "artifact", one - on the basis of similarity for visual sign "natural fact"), and only one terminological unit is a metaphor based on the structural type of similarity.

Key words: conceptual metaphor, theory, transference, type, gestalt, similarity. 
Постановка проблеми. Дослідження метафори вже не одне століття привертає увагу науковців, зокрема, представників таких галузей, як філософія, логіка i, звичайно ж, лінгвістика. Інтерес до метафори сприяв взаємодії названих напрямів наукової думки та їх понятійному взаємопроникненню. Внаслідок стрімкого розвитку усіх сфер науки, техніки та суспільно-політичного життя, виникає потреба номінувати нові поняття з допомогою неологізмів, або ж існуючими засобами мови. У даному випадку мова йдеться про метафоризацію - механізм, який дозволяє осягнути нову змістовну область через іншу, раніше засвоєну людиною. У нашій роботі ми розглядаємо особливості концептуальної метафори прикордонної сфери.

Мета статті - узагальнити основні особливості функціонування концептуальної метафори в прикордонній сфері.

Аналіз досліджень. Поява нового погляду на мислення як не просто на формально-логічний феномен, котрий володіє творчим характером, спричинило зміну трактування метафори як когнітивного феномена. На початку XX століття широке поширення набули ідеї інтеракціоністської концепції метафори, яка була введена А. Річардсом. Він розглядав метафору як взаємодію двох різних думок про два різні явища всередині одного слова (Річардс, 1990: 44-67). М. Блек звернув увагу на те, що пізнання світу і його інтерпретація в лінгвістичних термінах здійснюються людиною і обумовлені іiі здатністю співвідносити вже відоме з знову пізнаваним. У цьому сенсі «...продуктивність метафори полягає в притаманному їй властивості зіставляти, а потім синтезувати суті різних логічних порядків. При цьому зіставлення і синтез мають своїм результатом вибір того чи іншого підстави метафори». Значення метафори $\epsilon$ результатом взаємодії двох думок, що б'ють в одну точку. Таким чином, М. Блек розглядав метафору як результат семантичного ізоморфізму між двома суб' єктами - допоміжним і головним, що відбувається на тлі певного контексту. М. Блек був одним 3 перших дослідників, які з'єднали метафору 3 мовою конкретної наукової парадигми - філософії і обгрунтували необхідність її включення в спектр філософського інтересу (Блек, 1990: 158). Майкл Редді вказує, що метафора провідника не $є$ конкретним виразом; він вважає, що метафоричні припущення дозволяють використовувати ряд загальних виразів, і вони є здатними донести сенс думок до слів (Orthony, 1993).

На сьогодні увага до дослідження метафоризації спеціальних термінів зростає. З'являються праці, в центрі дослідження є аналіз ролі мета- фори у різних видах дискурсу та у різних термінологічних системах: медичній (Вострова, 2003), економічній (Лут, 2007), політичній (Балашова, 2007) тощо. Так, нами були проаналізовані роботи Н. Овчаренко (Овчаренко, 2013), в якій дослідниця окреслює основні особливості метафори в професійній мові з позиції когнітивістики, Ю. Рожкова, де автор характеризує механізм метафоризації у сфері англомовної термінології ветеринарної медицини (Рожков, 2020), О. Винник, в якій автор аналізує роль концептуальної метафори в сучасному англомовному дискурсі програмування (Винник, 2014).

Виклад основного матеріалу. Метафора допомагає встановлювати подібність між різними елементами людського досвіду, що визначає іiї величезнурольупрактичномуітеоретичномумисленні.

Сприйняття людиною навколишнього світу здійснюється за посередництва мови. Реалії зазнають категоризації та концептуалізації і включаються в наукову картину світу. Освоєні за допомогою вищезгаданих механізмів поняття є орієнтирами в осягненні і пізнанні світу, що мотивують i спрямовують пошук щодо вивчення нових, науково не оброблених понять. У своїй роботі ми погоджуємося з Д. Шапран у тому, що у метафоричній номінації відбиваються особливості концептуалізації дійсності в процесі іiї наукового осмислення (Шапран, 2016: 527).

Необхідність використання метафори в мові науки (в нашому випадку - у прикордонному термінознавстві) викликана тим фактом, що коло понять $\epsilon$ завжди ширшим, ніж існуючий мовний інвентар. Як зазначають I. Ільїнська, М. Платонова та Т. Смірнова у своїй статті, присвяченій метафоричним термінам, «...в технічних текстах метафоричні терміни часто використовуються для позначення понять, які ще не отримали назву. Вони виконують декілька функцій: розширяють межі переданої інформації, в той же час стискаючи інформацію розширенням значення існуючої лінгвістичної одиниці, вони фіксують нові значення, визначаючи нові концепти. Такі терміни неможливо описати традиційними категоріями через їхню складну семантичну структуру і їх потенціал різноманітних значень можливо виявити лише в конкретній комунікативній обстановці» (Ільїнська, 2013).

Сучасна когнітивна лінгвістика розглядає метафору не як мовний зворот чи спосіб семантичного словотвору або особливий вид переносного значення, а як базовий механізм людського мислення. На цьому етапі розвитку мовознавства когнітивна лінгвістика пояснює явища метафоризації з точки зору теорії концептуальної метафори 
(ТКМ). Дж. Лакофф та М. Джонсон, автори теорії концептуальної метафори, у своїй праці описують концептуальну метафору як перетин знань про одну концептуальну область в інший концептуальній області. В основі метафоризації лежить процес взаємодії між структурами знань (фреймами, сценаріями, схемами) двох концептуальних сфер - сфери джерела (source domain) та сфери цілі (target domain). Сфера джерела - конкретніша, відома з безпосереднього досвіду, антропоцентрична - через односпрямовану метафоричну проєкцію (metaphorical mapping) "постачає" знаки для менш зрозумілої концептуальної сфери мішені, тож метафора стає містком від очевидного до менш очевидного (Лакофф, 2008). Інакше кажучи, концептуальна метафора - це є результат відображення знань і досвіду однісї концептуальної сфери в іншій концептуальній сфері.

Згідно з ТКМ метафора $є$ властивістю мислення, а метафоричні вирази і вислови в мові $\epsilon$ лише поверхневим вираженням концептуальних метафор, що лежать в їх основі. Таким чином, у межах ТКМ метафора здобуває нове визначення як «розуміння та сприйняття однісї речі в категоріях (або через призму) іншої» (Lakoff, 1980). А.Ченкі визначає метафору як «спосіб думати про одну сферу через призму іншої» (Ченкі, 2002). В. Телія вбачає в метафорі такий спосіб мислення про світ, який використовує набуті знання. На його основі виникає уявлення про метафору як про модель знання: 3 певного ще не чітко «осмисленого» поняття формується новий концепт за рахунок використання буквального значення вираження і асоціацій, які його супроводжують (Телія, 1988). К. Лут, описуючи явище «концептуальна метафора», пояснює, що одним із наслідків процесу відображення знань і досвіду однієї сфери в іншій концептуальній сфері є транстермінологізація, тобто «міграція» термінів з однієї системи знань до іншої з повним або частковим їх переосмисленням та перетворенням на міжгалузеві омоніми, що дає змогу вважати концептуальну метафору одним із найпродуктивніших засобів формування вторинних назв. При цьому первинне значення переосмисленого терміна може викликати підсвідомі асоціації, що сприяе емоційнішому та об'ємнішому сприйняттю інформації (Лут, 2007). А. Мартинюк зазначає, що концептуальні метафори втілюються конвенціональними одиницями мовлення (переважно, вільними словосполученнями). Такі конвенціональні одиниці, як правило, не усвідомлюються як метафори пересічними носіями мови, оскільки вони не мають яскраво вираженої образності і до того ж доволі часто використовуються у повсякденній мові (Мартинюк, 2017).

Прикордонна сфера - це $є$ менш предметна галузь, ніж, наприклад, технічні і природничі галузі, де метафоричний перенос здійснюється в основному на основі функціональної чи зовнішньої подібності. У нашому випадку просліджується метафоризація за асоціативною ознакою. Розглянемо приклади прикордонних термінологічних одиниць, опираючись на класифікацію метафор за видом перенесення, запропоновану О. Селівановою. Отже, згідно із способом взаємодії донорської та реципієнтної зони, вчена виокремлює три види метафоричного перенесення:

1. Структурний різновид характеризує інтеграція «донорської та реципієнтної зон на підставі однієї спільної когнітивної ознаки, яка в інтегрованих структурах знань належить до пропозиційних ядерних складників».

2. Дифузний різновид грунтується на «інтеграції донорської та реципієнтної зон на підставі спільного сценарію або комплексу асоціації».

3. Гештальтний різновид «полягає в застосуванні знаків донорських зон на позначення реципієнтних структур знань на підставі стереотипного уподібнення зорових, слухових, одоративних, тактильних, смакових гештальтів» (Селіванова, 2010: 207).

Ми не можемо не погодитися 3 думкою Л. Івіної, що метафори, завдяки своїй образності, здатні замінити недостатню академічність і точність номінації (Ивина, 2003).

Нами було виявлено вісім термінів-метафор, які належать до прикордонної сфери: honeycomb grid,kiss cut, rainbow printing, red ID card, blue ID card, saw-tooth edge, green border, blue border.

1. Honeycomb grid (глибокий друк документу у вигляді стільникової сітки)- гештальтний різновид метафори, який будується на схожості зорових образів. Донорська зона - натурфакт (продукт природного походження - бджолинні соти), реціпієнтна зона - артефакт («решітка»).

2. Kiss cut (технологія, яка застосовується при приклеюванні візової етикетки) - структурний різновид схожості, який базується на схожості дій людини (поцілунок, поріз). У даному випадку, дієслово «kiss» імітує дотик.

3. Rainbow printing (райдужний друк) гештальтний різновид метафори, де мотиваційною ознакою $є$ натурфакт «веселка». Знак донорської зони «природний об'єкт» (різнобарвність веселки) застосовується для позначення реціпієнтної зони «артефакт» (вид друку) на підставі зорової подібності. 
4. Red ID card (ідентифікаційна картка з високим рівнем доступу) - гештальтний різновид метафори, де перенесення відбувається на підставі стереотипного уподібнення зорового гештальту «колір». Червоний колір традиційно асоціюється із небезпекою та забороною і зустрічається у різних сферах науки (зокрема, у технічних та природничих науках - мухомор як втілення небезпеки отруєння чи червоне світло світлофору у правилах дорожнього руху, ізнайактуальніших-червона епідеміологічна зона поширення вірусу COVID-19).

5. Blue ID card (ідентифікаційна картка з загальним рівнем доступу)- метафора, значення якої тісно пов'язане із символічним перенесенням у попередньому прикладі (red ID card). Тобто, якщо у метафорі "red ID card" червоний колір уособлює заборону, застереження чи підвищену увагу, то синій колір, відповідно, володіє меншим ступенем емоційного забарвлення i традиційно асоціюється із стандартним рівнем функціонування будь-чого. За класифікацією, дана метафора теж належить до гештальтного різновиду метафори, де перенесення відбувається на підставі стереотипного уподібнення зорового гештальту «колір». При аналізі двох вищезазначених метафор можемо говорити про градацію у ступені вираження емоційного забарвлення значення. Дійсно, використання зорових перенесень при утворенні метафор спричиняє посилення образного сприйняття терміна, особливо на початкових етапах його існування.

6. Saw-tooth edge (зубчастий край(документа) гештальтний різновид артефактної метафори, яка будуєтьсянаосновістереотипногоуподібненнязорових образів (saw-tooth - пилка). Суть перенесення полягає в схожості форми краю документу до рукотворного предмету «пилка» (за наявністю зубців).
7. Green border (сухопутний кордон) - як i red ID card та blue ID card - це $\epsilon$ гештальтний різновид метафори, де перенесення відбувається на підставі стереотипного уподібнення зорового образу «колір». Значення елементів реалізується за кольором: зелений $\epsilon$ втіленням поняття «рослинний».

8. Blue border (морський кордон) - є комплементарним антонімом терміну «green border» i, відповідно, також належить до гештальтного різновиду метафори із перенесенням на підставі стереотипного уподібнення зорового гештальту «колір». Блакитний колір виступає втіленням концепту «вода» і у прикордонній сфері уособлює водойми, по яких проходять кордони України.

Висновки. Отже, застосування концептуальної метафори у прикордонній сфері відіграє важливу епістеміологічну роль. Метафора $є$ інструментом імплементації прикордонних понять, які потребують номінації чи оновлення. Як і інші сфери науки та діяльності, прикордонна сфера розширює свій вокабуляр шляхом застосування людського досвіду та пізнання в якості метафоричного переносу. Із восьми проаналізованих метафор сім належать до гештальтного різновиду метафори, які будуються на основі схожості зорових образів «колір» (чотири термінологічні одиниці) «артефакт» (одна ТО), «натурфакт» (дві ТО). Одна метафора базується на структурному виді схожості. Отже, гештальтний різновид зорової метафори є домінуючим серед виявлених метафоричних термінів прикордонної сфери. На нашу думку, поширення явища «метафоризація» у термінологічному вокабулярі прикордонної сфери $\epsilon$ зумовленим активним взаємообміном між спеціалізованими галузями та загальновживаною лексикою і не суперечить основним вимогам до терміна - стислості, влучності та однозначності.

\section{СПИСОК ВИКОРИСТАНИХ ДЖЕРЕЛ}

1. Lakoff G., Johnson M. Metaphors we live by. Chicago; L.: The Univ. of Chicago Press, 1980. 256 p.

2. Ortony A. (Ed.). Contents. In Metaphor and Thought (2nd ed., pp. vii-x). toc, Cambridge: Cambridge University Press, 1993. URL: https://msu.edu/ orourk51/800-Phil/Handouts/Readings/Linguistics/Reddy-TheConduitMetaphor-1979.pdf (дата звернення: 26.11.2020).

3. Балашова С. С. Варіативність метафоричних моделей у німецькомовному політичному дискурсі. Науковий вісник Волинського державного університету імені Лесі Украӥнки. № 3. 2007. С. 276-280.

4. Блэк М. Метафора. Теория метафоры:: сборник. М.: Прогресс, 1990. С. 153-172.

5. Винник О. Ю. Концептуальна метафора в сучасному англомовному дискурсі програмування. Наукові записки. Випуск 130. Серія: Філологічні науки (мовознавство). Кіровоград: РВВ КДПУ ім. В. Винниченка, 2014. С. 85-87.

6. Вострова С. В. Лінгвокогнітивні та комунікативно-прагматичні особливості сучасного англомовного медичного дискурсу (на матеріалі медичних текстів з проблематики ВІЛ/СНІДу) : автореф. дис. на здобуття наук. ступеня канд. філол. наук : спец. 10.02.04 “Германські мови”; Київ. нац. ун-т ім. Т. Шевченка. Київ, 2003. 20 с.

7. Ивина Л. В. Лингвокогнитивные основы анализа отраслевых терминосистем (на примере англояз. терминологии венчур. финансирования). М.: Акад. проект, 2003. С. 176-195.

8. Ільїнська Л., Платонова М., Смірнова Т. Метафоричні терміни: невловима магія трансформації значення. Збірник матеріалів 19-го європейського симпозіуму по мовам для спеціільних цііей, 8-10 липня 2013, Відень. Австрія. URL: https://glebov.com.ua/metaforychn\%D1\%96-term\%D1\%96ny.html (дата звернення: 23.11.2019). 
9. Лакофф Д., Джонсон М. Метафоры, которыми мы живём / пер. с англ.; под ред. Баранова А. Н. 2-е изд. Москва: Издательство ЛКИ, 2008. 256 с.

10. Лут К. А. Концептуальна метафора в економічній літературі. Мова і культура. Київ: Вид. Дім Дм. Бураго, 2007. Вип.9, Том IV. С. 77-79.

11. Мартинюк А. П. Відтворення англійських конвенціональних метафор емоцій в українських перекладах. Вісник ХНУ імені В. Н. Каразіна. Серія: Іноземна філологія. Методика викладання іноземних мов. 2017. № 85. С. $21-28$.

12. Овчаренко Н. І. Метафора як когнітивний механізм категоризації фахових знань. Науковий часопис НПУ імені М. П. Драгоманова. Серія 10 : Проблеми граматики і лексикології української мови. 2013. Вип. 10. С. 111-114. URL: http://nbuv.gov.ua/UJRN/Nchnpu_10_2013_10_28 (дата звернення: 26.11.2020).

13. Ричардс А. Философия риторики. Теория метафоры: сборник. М.: Прогресс, 1990. С. 44-67.

14. Рожков Ю. Г. Метафоризація в англомовному термінологічному полі «хвороби тварин» у лінгвокогнітивному аспекті. Вісник Харківського національного університету імені В. Н. Каразіна. Серія «Філологія». Вип. 84, мовознавство, 2020, С. 56-61.

15. Селіванова О. О. Лінгвістична енциклопедія. Полтава: Довкілля, 2010.844 с.

16. Телия В. Н. Метафоризация как основной прием создания лексических и фразеологических средств языковой картины мира. Роль человеческого фактора в языке. Язык и картина мира / под ред. Б. А. Серебренникова, Е. С. Кубряковой и др. Москва: Наука, 1988. С. 38-62.

17. Ченки А. Семантика в когнитивной лингвистике. Современная американская лингвистика: фундаментальные направления / под ред. А. А. Кибрика, И. М. Кобозевой, И. А. Секериной. Москва: УРСС, 2002. С. 340-366.

18. Шапран Д. П. Мілітарна метафора в українській маркетинговій термінології. Молодий вчений. № 5 (32), травень 2016 р. С. 526-530.

\section{REFERENCES}

1. Lakoff G., Johnson M. Metaphors we live by. Chicago; L.: The Univ. of Chicago Press, 1980. $256 \mathrm{p}$ [in English].

2. Ortony A. (Ed.). Contents. In Metaphor and Thought (2nd ed., pp. vii-x). toc, Cambridge: Cambridge University Press, 1993. URL: https://msu.edu/ orourk51/800-Phil/Handouts/Readings/Linguistics/Reddy-TheConduitMetaphor-1979. pdf (Last accessed: 26.11.2020) [in English].

3. Balashova S. S. Variatyvnist metaforychnykh modelei u nimetskomovnomu politychnomu dyskursi [Variability of metaphorical models in German-language political discourse]. Naukovyi visnyk Volynskoho derzhavnoho universytetu imeni Lesi Ukrainky [Scientific Bulletin of Lesya Ukrainka State University of Volyn]. No. 3. 2007. Pp. $276-280$ [in Ukrainian].

4. Black M. Metafora [Metaphor]. Teoriia metafory: sbornik [Metaphor theory: collection]. M.: Progress, 1990. Pp. 153-172 [in Russian].

5.Vynnyk O. Yu. Kontseptualna metafora v suchasnomu anhlomovnomu dyskursi prohramuvannia [Conceptual metaphor in modern English programming discourse]. Naukovi zapysky [Scientific notes]. Vypusk 130. Seriia: Filolohichni nauky (movoznavstvo). Kirovohrad: RVV KDPU im. V. Vynnychenka, 2014. Pp. 85-87 [in Ukrainian].

6. Vostrova S. V. Linhvokohnityvni ta komunikatyvno-prahmatychni osoblyvosti suchasnoho anhlomovnoho medychnoho dyskursu (na materiali medychnykh tekstiv z problematyky VIL/SNIDu) [Linguocognitive and communicative-pragmatic features of modern English-language medical discourse (based on medical texts on HIV/AIDS] : avtoref. dys. na zdobuttia nauk. stupenia kand. filol. nauk : spets. 10.02.04 "Hermanski movy" [author's ref. dis. for Degree of Cand. of Philol.: spec. 10.02.04 “Germanic Languages”]; Kyiv. nats. un-t im. T. Shevchenka. Kyiv, 2003. 20 p [in Ukrainian].

7. Ivina L. V. Lingvokognitivnye osnovy analiza otraslevykh terminosistem (na primere angloiaz terminologii venchur finansirovaniia) [Linguo-cognitive foundations of the analysis of industry terminology systems (on the example of English terminology of venture financing)]. M.: Akad. proekt, 2003. Pp. 176-195 [in Russian].

8. Ilinska L., Platonova M., Smirnova T. Metaforychni terminy: nevlovyma mahiia transformatsii znachennia [Metaphorical terms: elusive magic of meaning transformation]. Zbirnyk materialiv 19-ho yevropeiskoho sympoziumu po movam dlia spetsialnykh tsiei [Proceedings of the 19th European Symposium on Languages for Special Studies], 8-10 lypnia 2013, Viden. Avstriia. URL: https://glebov.com.ua/metaforychn\%D1\%96-term\%D1\%96ny.html (last accessed: 23.11.2019) [in Ukrainian].

9. Lakoff D., Dzhonson M. Metafory kotorymi my zhivem / per s angl.; pod red. Baranova A. N. 2-e izd [Metaphors we live by / transl. from English; ed. Baranov A.N. 2nd ed]. Moskva: Izdatelstvo LKI, 2008. 256 p [in Russian].

10. Lut K. A. Kontseptualna metafora v ekonomichnii literaturi [Conceptual metaphor in economic literature]. Mova $i$ kultura [Language and culture]. Kyiv: Vyd. Dim Dm. Buraho, 2007. Vyp.9, Tom IV. Pp. 77-79 [in Ukrainian].

11. Martyniuk A. P. Vidtvorennia anhliiskykh konventsionalnykh metafor emotsii v ukrainskykh perekladakh [Reproduction of English conventional metaphors of emotions in Ukrainian translations]. Visnyk KhNU imeni V. N. Karazina. Seriia: Inozemna filolohiia. Metodyka vykladannia inozemnykh mov [Bulletin of V.N. Karazin KhNU. Series: Foreign Philology. Methods of teaching foreign languages]. 2017. No. 85. Pp. 21-28 [in Ukrainian].

12. Ovcharenko N. I. Metafora yak kohnityvnyi mekhanizm katehoryzatsii fakhovykh znan [Metaphor as a cognitive mechanism of categorization of professional knowledge]. Naukovyi chasopys NPU imeni M. P. Drahomanova [Scientific journal of NPU named after MP Drahomanov]. Seriia 10: Problemy hramatyky i leksykolohii ukrainskoi movy. 2013. Vyp. 10. Pp. 111-114. URL: http://nbuv.gov.ua/UJRN/Nchnpu_10_2013_10_28 (last accessed: 26.11.2020) [in Ukrainian].

13. Richards A. Filosofiia ritoriki [Philosophy of rhetoric] // Teoriia metafory: sbornik [Metaphor theory: collection]. M.: Progress, 1990. pp. 44-67 [in Russian].

14. Rozhkov Yu. H. Metaforyzatsiia v anhlomovnomu terminolohichnomu poli «khvoroby tvaryn» u linhvokohnityvnomu aspekti [Metaphorization in the English-language terminological field of "animal diseases" in the linguocognitive aspect]. 
Visnyk Kharkivskoho natsionalnoho universytetu imeni V. N. Karazina [Bulletin of V.N. Karazin Kharkiv National University]. Seriia «Filolohiia». Vyp. 84, movoznavstvo, 2020, pp.56-61 [in Ukrainian].

15. Selivanova O. O. Linhvistychna entsyklopediia [Linguistic encyclopedia]. Poltava: Dovkillia, 2010.844p [in Ukrainian].

16. Teliia V. N. Metaforizatsiia kak osnovnoi priem sozdaniia leksicheskikh i frazeologicheskikh sredstv iazykovoi kartiny mira [Metaphorization as the main method of creating lexical and phraseological means of the linguistic picture of the world]. Rol chelovecheskogo faktora $v$ yazyke. Yazyk $i$ kartina mira [The role of the human factor in language. Language and picture of the world]: pod red B.A. Serebrennikova, E.S. Kubriakovoi i dr. Moskva: Nauka, 1988. Pp. 38-62 [in Russian].

17. Chenki A. Semantika v kognitivnoi lingvistike [Semantics in Cognitive Linguistics]. Sovremennaia amerikanskaia lingvistika: fundamentalnye napravleniia [Contemporary American linguistics: Fundamental directions] / pod red. A. A. Kibrika, Y. M. Kobozevoy, Y. A. Sekerinoy. Moskva: URSS, 2002. Pp. 340-366 [in Russian].

18. Shapran D. P. Militarna metafora v ukrainskii marketynhovii terminolohii [Military metaphor in Ukrainian marketing terminology]. Molodyi vchenyi [Young scientist]. No. 5 (32), traven 2016 r. Pp. 526-530 [in Ukrainian]. 